\title{
Implications of Adopting Drip Irrigation System on Crop Yield and Gender-Sensitive Issues: The Case of Haramaya District, Ethiopia
}

\author{
Meseret Dawit ${ }^{1,2, *}$, Megersa Olumana Dinka ${ }^{1}$ and Olkeba Tolessa Leta ${ }^{3}$ (i) \\ 1 Department of Civil Engineering Sciences, Faculty of Engineering and the Built Environment, University of \\ Johannesburg APK Campus, P. O. Box 524 Johannesburg, South Africa; mdinka@uj.ac.za \\ 2 School of Water Resource \& Environmental Engineering, Haramaya Institute of Technology, \\ Haramaya University, P. O. Box 138 Dire Dawa, Ethiopia \\ 3 Bureau of Watershed Management and Modeling, St. Johns River Water Management District (SJRWMD), \\ 4049 Reid St, Palatka, FL 32177, USA; OLeta@sjrwmd.com \\ * Correspondence: Meseret.dawit@haramaya.edu.et
}

Received: 23 August 2020; Accepted: 21 September 2020; Published: 27 September 2020

check for updates

\begin{abstract}
Integration of advanced irrigation systems and technology is essential to improve crop water productivity and yields, especially in developing countries. This study aims at investigating the effects of adopting a drip irrigation system combined with hand-dug wells on crop water productivity and yields of household farmers and their perception on the proposed scheme over two cropping seasons in the Haramaya District, Ethiopia. We chose three locally called "Kebeles" within the District, and selected a certain number of household farmers that had similar characteristics within each Kebele. The selected farmers had practiced both the proposed drip irrigation with private hand-dug wells water supply (intervention pilots) and traditionally-used surface irrigation with communal water supply (non-intervention pilots) schemes. We also conducted interviews with the selected household farmers, personal observations, and measurements on crop water productivity and yields for both intervention and non-intervention pilots. We found that the proposed drip irrigation system significantly improved the crop productivity and yields of the farmers. More importantly, findings indicated that the use of drip irrigation system combined with hand-dug well water supplies reduced the over-exploitation of water (water savings) and labor-intensive manual-irrigation. The latter particularly helped women to work less on their farm works and thus provided them a flexible system to expand their plot sizes and grow a variety of crops. Overall, the drip irrigation system with water supply from hand-dug wells is highly recommended as it allows a flexible system for household farmers and provides an opportunity to expand their plot sizes with a variety of crops, which is also expected to mitigate the negative implications of climate change on freshwater water resources and crop productivity. However, the farmers of the Haramaya District expressed their need on capacity building, financial and technical supports from local to regional governments and other agencies to ensure an efficient and cost-effective drip irrigation system and to further improve their crop water productivity and yield, food self-sufficieny, and livelihoods. It is also important to consider market-based farming approaches, while promoting efficient irrigation systems and self-supply to ensure quick investment returns. This study recommends to adopt and expand the proposed drip irrigation system at household levels in Sub-Saharan and other similar regions.
\end{abstract}

Keywords: drip irrigation; crop yield; Haramaya District; household farmers; hand-dug wells 


\section{Introduction}

The global population has already reached about 7.8 billion, of which Africa accounts for about $17 \%$, and this number is predicted to reach about 10 billion by $2050[1,2]$. This continued increase in population growth, combined with urbanization and climate change, has already put pressure on existing freshwater resources, agricultural productivity, and food security systems of the globe $[1,2]$. In addition, climate change, driven by anthropogenic factors, is expected to impact riparian freshwater resource availability, ecosystem services, and socioeconomic and other environmental benefits [3-6]. However, the impacts have been expected to vary both spatially and temporally, which depend on socioeconomic, geographic, technology, culture, governance, and other environmental factors $[3,7,8]$. Consequently, there is a need for timely agricultural intervention to support the livelihood of the people that have been particularly affected by the frequent occurrence of water scarcity due to population growth and climate change $[9,10]$. This is especially a more prominent problem in developing countries, such as Ethiopia [11-13]. For example, the recent drought and flood occurred for the period from 2015 to 2016 in Ethiopia left over 10.2 million people without access to adequate food, which classified about one-quarter of all the Ethiopian Districts under severe food security and nutritious crisis [11]. Given the extreme climatic conditions of the country, Ethiopia has been experiencing a noticeable fluctuation in seasonal, spatial, and temporal variability of rainfall, including its amounts [14,15]. While rainfall change and irrigation water use are important factors that directly influence crop water productivity and yields, it has been highly acknowledged that other factors, such as soil nutrients and water storage, socio-economics factors, farming system, landscape, and farmers' perception, play significant roles on modern agricultural development [16-18].

Climate change affects the ecosystem services and domestic and agricultural water uses, as well as crop water productivity $[3,19,20]$. However, Bailey et al. [21] reported that implementing proper management of water resources might help to reduce the effects of climate change. Climate change generally affects the hydrological cycle processes and its components, such as groundwater recharge and base flows, surface runoff, and evapotranspiration, including human activities and agricultural practices, and natural ecosystem functioning [5,22]. Additionally, climate change can affect the biogeochemical processes, saltwater intrusion and freshwater quantity and quality, especially in coastal areas $[22,23]$. The impacts of climate change on freshwater resource availability and communities' livelihood have been well documented worldwide [24,25]. Therefore, several researchers have proposed to use innovative technologies, such as enhanced irrigation system to minimize the effects of climate change on crop water productivity and yields [26-28]. Moreover, such technologies are expected to reduce gender-sensitive issues related to agricultural practices, particularly in developing countries like Ethiopia [29,30].

The poor farmers of Ethiopia, who are largely dependent on rain-fed agricultural systems for their livelihoods, have been mostly affected by climate change [6,31]. There has been limited utilization and application of modernized agricultural techniques in Ethiopia, which is mainly due to the lack of stakeholders and beneficiary farmers participation [32-34]. While this has been happening worldwide, it has become apparent that such recurrent problems in Ethiopia have been more intensified, reaching the point that the Ethiopian people cannot address their problems by depending on the traditional food aid and emergency response actions [35,36]. Instead, the local, regional, and federal governments of the country yet need to search for localized, regionalized and large-scaled sustainable solutions and alternative water harvesting methods in order to eradicate food insecurity and mitigate the impacts of extreme climate conditions and change. However, Dile et al. [37] documented that a water harvesting implementation and mitigation measures to climate change require extensive studies that include socioeconomic analysis, available freshwater resources assessment, and stakeholder involvement among others so that sustainable water use and food security can be achieved.

Other input factors required for climate change mitigation and food security is the integration of a gender-based analytical framework, which aims at examining gendered-related outcomes for collective and transparent governance within a small-scale irrigated agriculture scheme [38]. This is of interest in 
Ethiopia as gender-specific analysis and effects have not been well incorporated and developed in irrigation development and crop productivity system of the country. This should be well understood and designed, and should tailor the participation of agricultural extension programmers both from female and male farmers, and it is expected to overcome gender-related and cultural limitations for irrigation system development in Ethiopia [30,38]. Not only stakeholders' participation and improving governance but also the use of advanced and innovative agricultural technologies have been highly recommended to enhance the agricultural productivity of Ethiopia $[39,40]$.

Previous studies have generally stated that Ethiopia needs to double its current cereal crop production by 2025 to meet the food security and self-sufficiency of its rapidly growing population $[15,41]$. In addition, according to the second Ethiopian Growth and Transformational Plan (EGTP) of the period from 2015 to 2020, the government needs to intensify the current agricultural production by increasing the size of arable and irrigated lands [42]. To achieve this demand and secure food self-sufficiency, there is a need to review the current chain of agricultural practices of the country $[15,43]$. Furthermore, irrigation has received attention as a means for supplementing the rain-fed farming system and improving agricultural crop productivity of the Ethiopian farmers. For example, the EGTP has envisaged a 60\% increase in irrigation systems by 2020 [42,44].

While Ethiopia has already planned to expand its irrigable land and increase crop productivity, modern irrigation systems application such as drip irrigation have not yet been widely practiced in the country, particularly at household levels $[45,46]$. However, creating opportunities to provide access to enhanced irrigation systems and improving irrigation water storage and supply systems have already proven to be an efficient and essential transformation approach to achieve enhanced and sustainable crop water productivity and yields elsewhere [32,45,46]. The drip irrigation system, one of the advanced irrigation and efficient ways of reducing water losses through evaporation during irrigation water application, has been widely recognized for enhancing crop water productivity and yields [6,45]. In addition, the improvement of irrigation systems and agricultural production is vital for sustainable financial development especially in sub-Saharan countries, such as Ethiopia [8,14,47]. For example, Jovanovic et al. [48] reported that crop yields increased by up to eight times with the use of appropriate innovative farming practices and irrigation technologies by small-scale farmers in Ethiopia, South Africa, and Tunisia. Such intensive and innovative farming systems combined with innovative technology transfer and capacity building are viable strategies to secure efficient scarce water utilization and food supplies for farmers and rural communities in Ethiopia and other developing countries [48,49]. However, while agriculture is the backbone of Ethiopia, such innovative agricultural farming and irrigation water saving systems have not been widely recognized and practiced, especially at household farmers [6,31,50]. In the past, although there have been a few attempts to introduce and promote water harvesting techniques for supplement irrigation of the rural farmers, the applications have largely failed due to lack of a customized approach, stakeholder involvement and knowledge transfers, good governance and practices, and use of modern communal irrigation systems [50-54]. In addition, if the current soil erosion and depletion of shallow wells in Ethiopia continue at the present rates, the groundwater levels are predicted to significantly lowered to a level where it requires a more advanced motorized drilling and pumping systems, which is beyond the capacities of current household farmers [51,55,56]. Therefore, it is necessary to develop strategies for watershed rehabilitation and improve water utilization and management of Ethiopia.

In Ethiopia, there have been no studies that assess and document the implications of introducing drip irrigation system and private hand-dug wells as irrigation water supply on crop water productivity and yields at household levels, especially in the eastern region of the country where water shortage is mostly prevalent. Hence, it is of interest to evaluate and compare the traditionally used surface irrigation system with the advanced drip irrigation system combined with a private hand-dug well for irrigation water supply in the eastern part of the country. Consequently, this study has selected the Haramaya Woredas, hereafter referred as District, from the eastern region of Ethiopia. Within the District, we selected three Kebeles that include Adelle, Damota, and Finkile. These Kebeles were 
selected because they have used drip irrigation systems combined with irrigation water supplies from hand-dug wells but it has been reported that the irrigation systems have often faced serious problems on infrastructural and institutional governance, and management systems [56]. Additionally, there has been little investment to conserve the watersheds in order to enhance groundwater and increase groundwater supply for irrigation water use [51,56-58]. In recent years, there has been nationwide watershed rehabilitation and conservation initiative programs to conserve water and soil and improve watershed freshwater resources and irrigation water supply $[32,33,58]$. However, problems related to institutional, infrastructural, and management aspects to irrigation systems have largely remained and unsolved yet [28,59-61]. This study utilized the three selected kebeles as case studies where the aforementioned challenges prevail at the farm and watershed levels of the study areas. For example, over-exploitation of water from the Haramaya Lake and groundwater in the lake's buffer zone has caused a significant decline in the lake's volume. This has eventually resulted in the drying out of the lake especially during the long dry seasons. Land degradation has also been further contributing to soil erosion and thus sedimentation of the lake. Moreover, gender parity and climate change have also had fundamental influences on the selected kebeles. Therefore, the objective of this study was to see the effects of adopting drip irrigation with a hand-dug well water supply scheme on crop water productivity and yields, including geneder-sensitive issues, in Adelle, Damota, and Finkile kebeles of the Haramaya District, East Hararghe Zone, Ethiopia.

The remaining parts of the paper are organized as follows. Section 2 provides the materials and methods used in this study. Section 3 presents results with a discussion, followed by conclusions and recommendations provided in Section 4.

\section{Materials and Methods}

The study area is situated inside the Lake Haramaya watershed, East Hararghe zone, Oromia region, Ethiopia (Figure 1). The total area of the watershed is $5032 \mathrm{ha}$, of which the Lake Haramaya covers about 226 ha [62]. While $70 \%$ of Haramaya District's climate falls under what is locally called "Woina Dega" (wet and cool), the remaining 30\% experience "Kolla" (dry and hot). The area receives a bimodal rainfall type with a mean annual precipitation of $751 \mathrm{~mm}$ [62]. According to Muleta et al. [50], the dry period that extends from October to January receives less than $30 \mathrm{~mm}$ of rain per month. December is the driest month of that period and only receives $9 \mathrm{~mm}$ of rain. For the wet season (February to September), February and March receive a rainfall amount of $37 \mathrm{~mm}$ and $67 \mathrm{~mm}$, respectively. August is the wettest month of the wet season with a rainfall value of $144 \mathrm{~mm}$ [51].

The major land-use types in the study area are farmland $(78.3 \%)$, grazing land $(7.6 \%)$, settlement $(4.5 \%)$, shrub (4.6\%), swamp (4.5\%) and forest $(0.6 \%)$. The Lake Haramaya watershed area is endowed with groundwater and thus there are several shallow wells within the watershed. The major crops grown in the area are sorghum and maize, including staple grains. Farmers close to the lake develop shallow wells for irrigating Khat or Chat and other vegetables (lettuce, carrot, onion, tomato and cabbage) $[62,63]$. The livelihood of the community in the Lake Haramaya Watershed is predominantly based on farming and livestock rearing [63]. However, the majority of the population lives under the poverty line. Consequently, some proportion of the populations are dependent on food aid that lasts for 3 to 6 months per year. Therefore, food security is a major issue particularly in the years of droughts. As the area does not have significant problems related to access to the market, the farm products, such as livestock, Khat, sorghum and vegetables are sold at nearby local markets. 

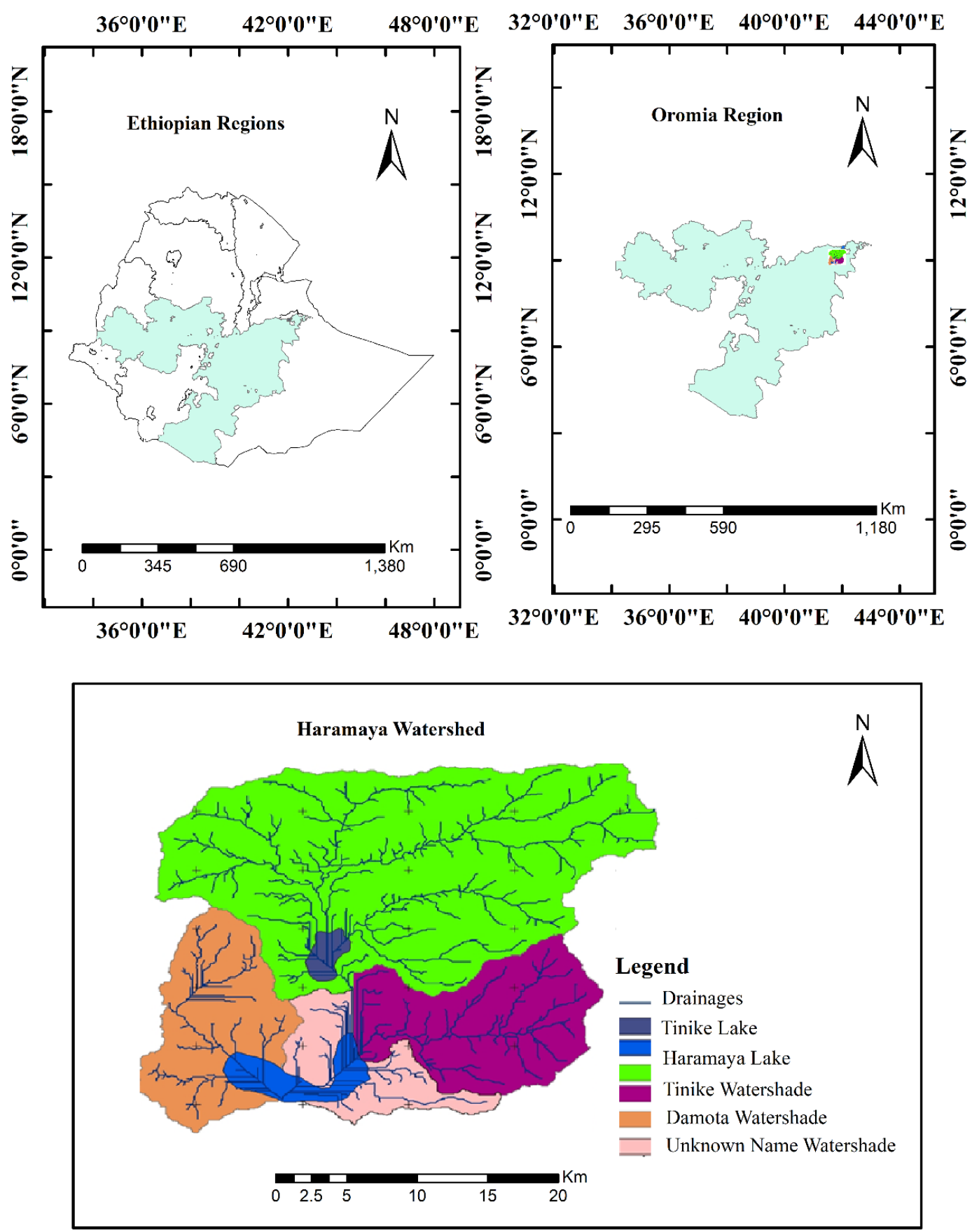

Figure 1. Location of the study area, the Lake Haramaya Watershed, Ethiopia Source: Elaborated by the Authors.

\section{Methodology}

A preliminary visit was carried out to all kebeles in the Haramaya District to select the pilot kebeles and smallhold (household) farmers to participate in this study. The three kebeles were selected based on their climate and hydrology (Table 1). The three selected kebeles have a high-groundwater table that can be easily accessed by manual excavation (hand-dug well). Such systems can also quickly recharge the hand-dug wells with an annual rainfall amount of $\geq 500 \mathrm{~mm}$ [64] and thus facilitate easy water harvesting practices. The selected kebeles were spatially distributed in the Haramaya District instead of concentrating on one District, for two main reasons: (1) to take into account for environmental factors (e.g., soil, slope, and rainfall) in the different areas of the District and (2) to investigate if the proposed irrigation technology could be applied to different kebeles of the District 
so that the method can be up-scaled to other similar kebeles within the District and elsewhere with similar characteristics.

Table 1. Selected kebeles and number of smallhold farmers for the intervention around Haramaya.

\begin{tabular}{cc}
\hline Kebele & Number of Smallhold Farmers \\
\hline Damota & 4 \\
Finkile & 3 \\
Adelle & 3 \\
\hline Total & 10 \\
\hline
\end{tabular}

Source: Field data of the research.

Representative farmers were selected from each of the three selected kebeles (Table 1) based on selection criteria and slight modifications methods used in other studies $[38,56]$. The criteria included (i) willingness to be the first to adopt the proposed irrigation technology, (ii) presence of males and females as farm leaders, (iii) condition of small-scale farmers (households) and, (iv) availability of a local person to support the farmers who don't have financial possibilities and need economic support. It should be mentioned that although irrigation has been practiced in the area, drip irrigation was found to be new to most of the selected farmers. Therefore, on-farm training was needed and organized to raise awareness about the efficiency of drip irrigation system, development of private water sources, such as from shallow wells that should focus on the portion of the household's land, farm investment, and environmental conservation program for all selected household farmers of the three selected kebeles. This has been considered either for the pilot or non-pilot household farmers.

Once household farmers were selected for the three kebeles as shown in Table 1, drip irrigation systems, which are reasonably affordable to the household farmers, were provided to the farmers through projects $[14,65]$. The application of modern and drip irrigation systems was demonstrated to the farmers. The selected household farmers were trained in the development of a hand-dug well and water lifting schemes. They were also given exercises on the installation and management of the irrigation kits and water lifting systems. Ten drip irrigation pieces of equipment and water lifting schemes were installed in 10 household farms. Farmers excavated wells on their own and/or in collaboration with other farmers. Considering the hydrology and pre-existing irrigation practices in the area, hand-dug wells were selected as sources of self-provided water supply system for the farmers.

After providing training to the selected farmers on constructing hand-dug wells and water-lifting schemes, we continuously monitored and checked if the farmers had correctly constructed their own hand-dug wells and water-lifting systems. Then, drip irrigation kits were distributed to them. The drip irrigation kits were provided by the project and the emitters were selected through a group discussion that is mainly focused on the need of farmers as well as their cost-effectiveness. Drip irrigation installation was carried out with support from the District's water technicians and kebele's development agents. Farmers were also trained on the management and use of the drip irrigation kits. At the same time, fifty household farmers were selected from the three selected kebeles as a control, whereby the new drip irrigation and water-lifting schemes were not adopted.

Once the irrigation and water supply systems were successfully implemented, various data, such as crop yield, Y (ton/ha) and water productivity (WP) were collected for the selected household farmers. WP was estimated as the ratio between the crop yield and the amount of irrigation water used to irrigate the crops (potatoes, carrots, garlic, onions, cabbage and maize) [44,54]. We simultaneously created a group discussion to get perception and general acceptance of the new drip irrigation and self-provided water supply schemes. Additionally, we performed interviews for data collection using formulated questionnaires. We conducted interviews and focus group discussions with the kebele leaders, farmers' representatives, representatives of agricultural development workers and stakeholders. We also held a focal group discussion was in the three kebeles of the pilot study areas (Damota, Finkile and Adele). We selected a total of 60 respondents, 20 from each kebele (Table 2). 
Ten of the total respondents were intervention/pilot smallhold farmers (those used proposed drip irrigation and hand-dug wells for irrigation water supply schemes), while 50 were non-intervention (non-pilot) household farmers (Table 2). We carried out the study for both the intervention and non-intervention households of the selected three kebeles. It should be noted that the non-intervention household farmers had similar socio-economic status and farm size to the intervention household farmers. We used such approaches to collect data from farmers with similar characteristics and for the easy comparison of the results.

Table 2. Distribution of smallhold farmer's respondents.

\begin{tabular}{cccc}
\hline Kebele & $\begin{array}{c}\text { Intervention } \\
\text { Smallholder Farmers }\end{array}$ & $\begin{array}{c}\text { Non-Intervention } \\
\text { Smallholder Farmers }\end{array}$ & Total Farmers \\
\hline Damota & 4 & 16 & 20 \\
Finkile & 3 & 17 & 20 \\
Adelle & 3 & 17 & 20 \\
\hline
\end{tabular}

Source: Authors elaboration for field experiment of the research.

We carried-out comparative analysis to investigate the productivity between the pilot and non-pilot farmlands. We measured the productivity as yield divided by irrigation water applied during the growing season assuming all other factors, such as the use of fertilizers, seed type, and farm management to be similar. We compared the results obtained from the pilot household farmers with those of the non-pilot household farmers. We also used interviews and focus group discussions to evaluate the perception and acceptance of farmers to the newly introduced self-supply water and drip irrigation systems.

\section{Results and Discussion}

\subsection{Respondent Characteristics}

In order to provide insight into the characteristics of the respondents, we collected some background information about the smallhold farmers (respondents) using questionnaires. Figure 2 presents a graphical plot of the gender classification of the farm leader of the household farmers. The figure also presents the literacy classification of the farmers-whether they can read and write, and the age group classification across the three selected kebeles.

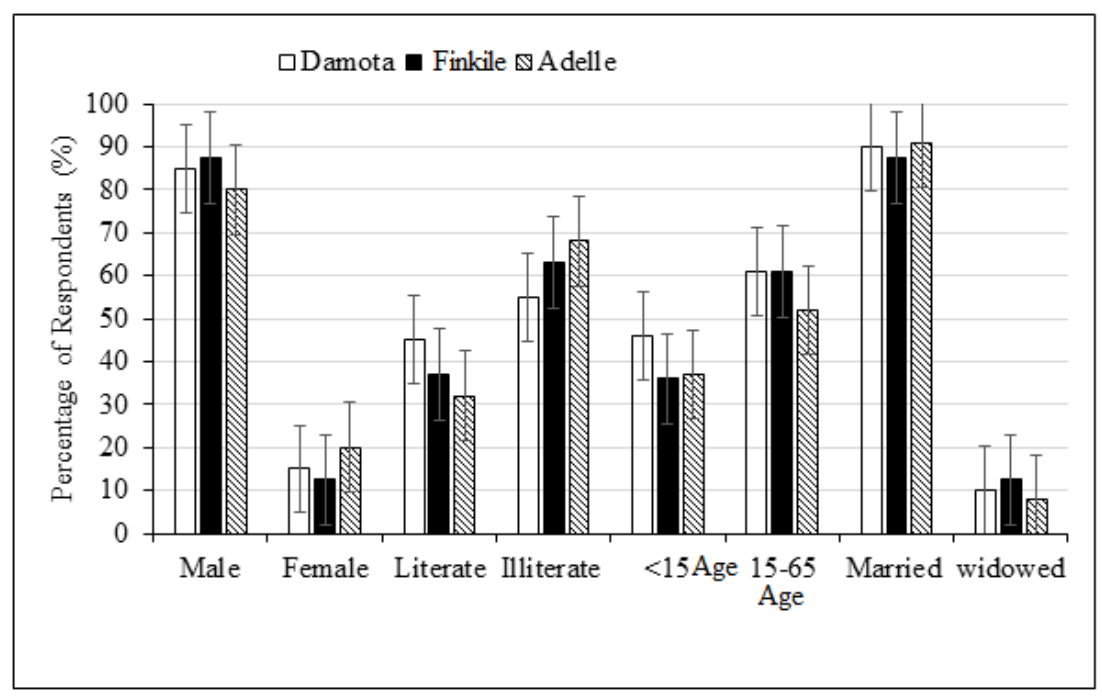

Figure 2. Background information of respondents used for this study. Source: Elaborated by the Authors. 
The household composition of respondents in the three kebeles is similar, with small variations in literacy level. Damota had the highest percentage of literate farmers (Figure 2), which is attributed to its proximity to Haramaya town that has more schools than other parts of the District. Male farmers lead most of the household farms with the majority of the respondents being in the age range of 15 to 65 years (Figure 2). According to the respondents, widows led all the female-led household farms.

\subsection{Farmland Characteristics}

The study revealed that $87 \%$ of the respondents own their farmland. The average size of the farmlands of the household farmers is 0.5 hectares. The majority of the respondents $(67 \%)$ stated that their farm sizes are small, such that it does not meet their household demands. Consequently, it is insufficient to grow enough crops for their household consumption and to generate income. They also complained that their farm sizes also decrease with time because of land division among the family members. Considering their land fertility for crop production, $86 \%$ of the respondents rated their lands as moderately fertile, while $14 \%$ of them rated their land as slightly degraded. We also asked the farmers to rate the trend of production in the past 10 years. Figure 3 shows the crop production trend for the three kebeles. The majority (54\%) of the total respondents reported a decline in crop yields; $39 \%$ reported steady crop production and only $7 \%$ of the respondents reported an increase in production. The major causes for the declining trend in crop yields, as identified by the respondents, are presented in Figure 4. Some of the main causes include a shortage of supplementary irrigation water sources, lack of draught oxen, deterioration in soil fertility, and drought and shortage of cultivated land, which are in agreement with the previous studies [28,46].

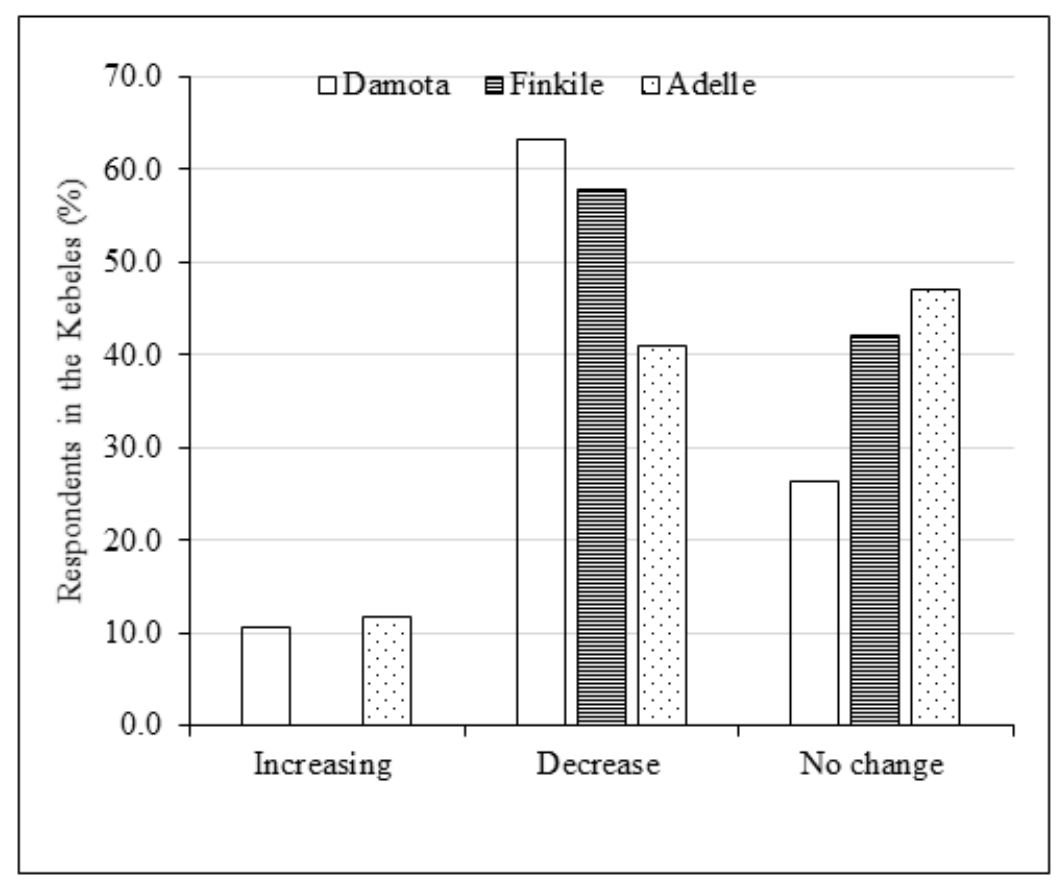

Figure 3. Crop yield trend within the last 10 years of the three selected kebeles of the Haramaya District (Source: Elaborated by the Authors).

The respondents, however, stated that they apply different mechanisms to enhance their crop productivity based on their own knowledge gained through experience and the support of the kebele's development agents. For example, in order to improve their land and crop productivities, they also practiced crop rotation, composting, and fallowing (Figure 5). Figure 5 clearly shows that crop rotation was the most preferred method of enhancing the productivity of the farmlands for all the three selected kebeles. 


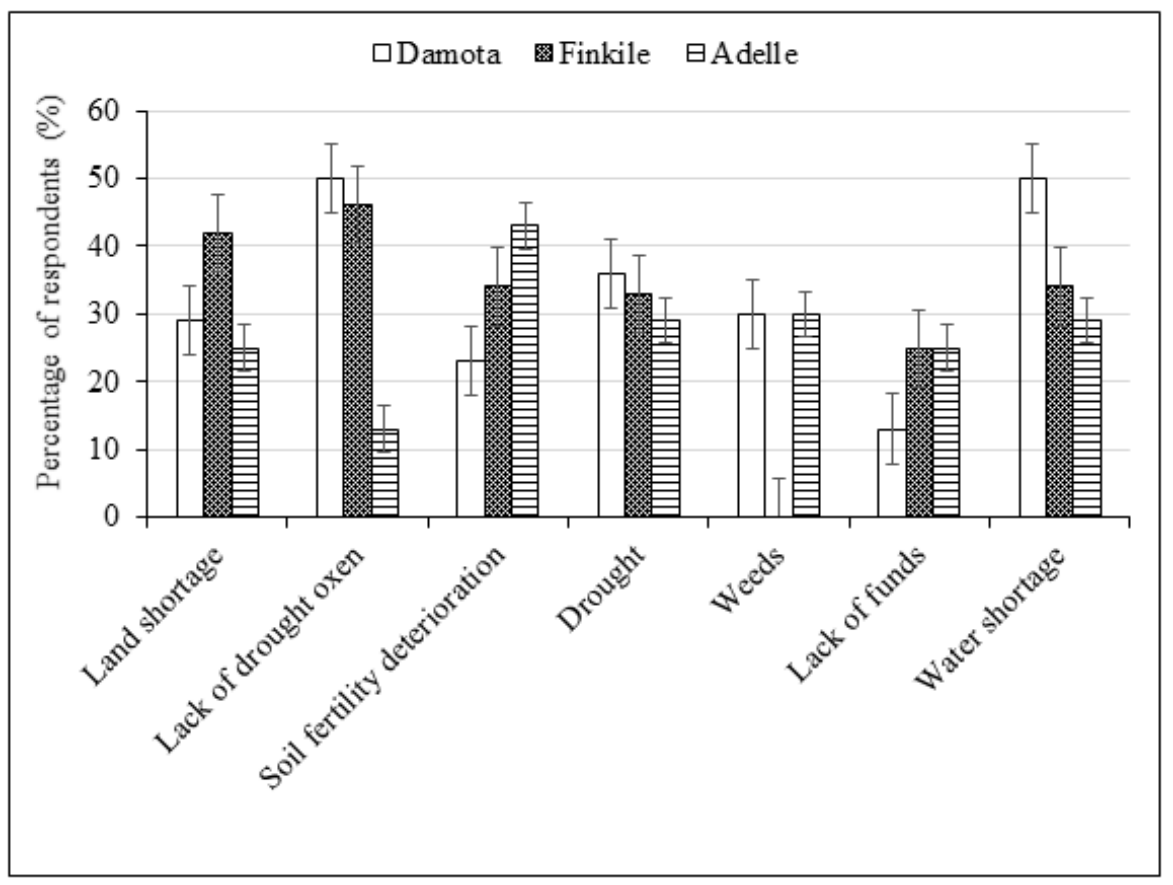

Figure 4. Causes of crop yields decline in the past 10 years of the three selected kebeles of the Haramaya District (Source: Elaborated by the Authors).

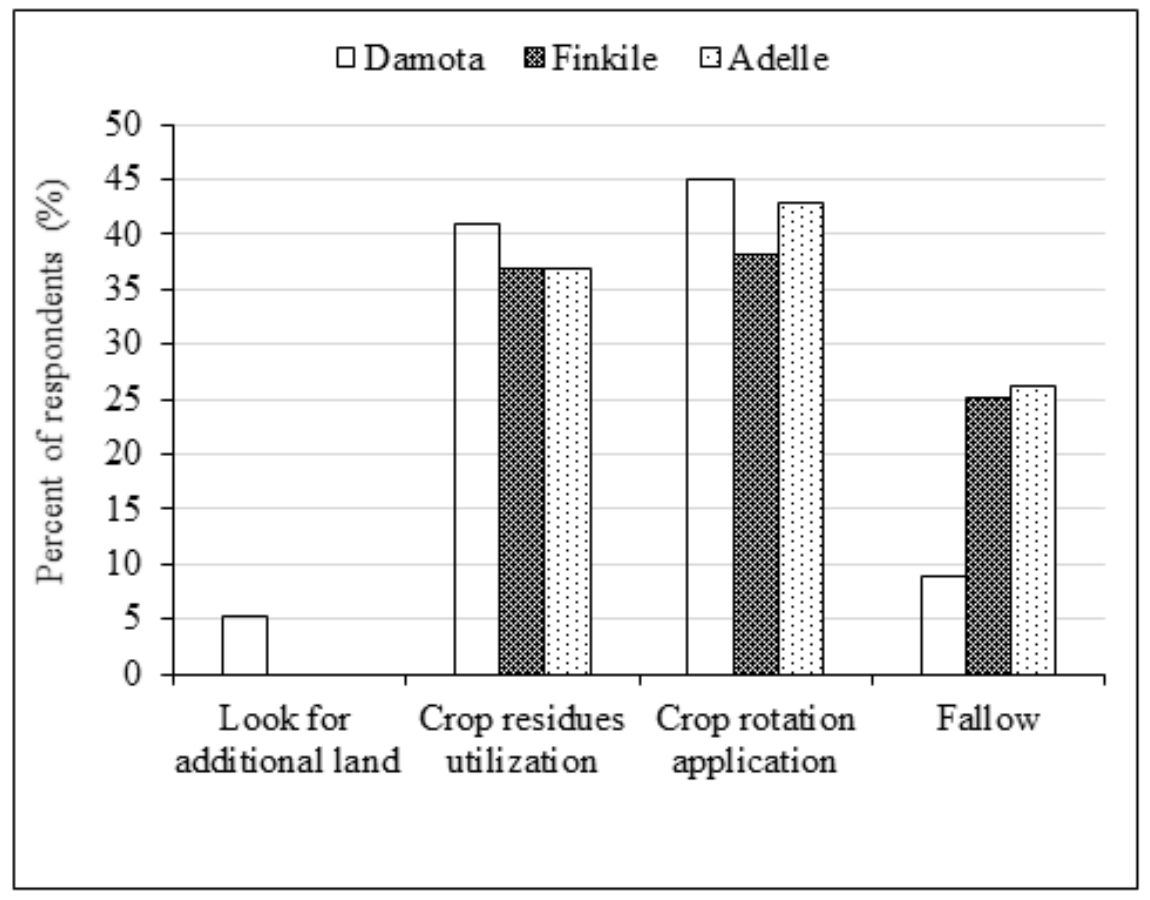

Figure 5. The measures taken by the farmers of the three kebeles post-crop ( Source: Elaborated by the Authors).

Additionally, while farmers from the Finkile Kebele favored cropping their land once in a year, farmers of the Damota and Adelle Kebeles favored growing their crops two or more times a year (Figure 6). However, none of the farmers changed the use of their land from farming to other forms of land utilization. This is because it is their source of livelihood. Consequently, they strive to cultivate their land even under challenging situations. 


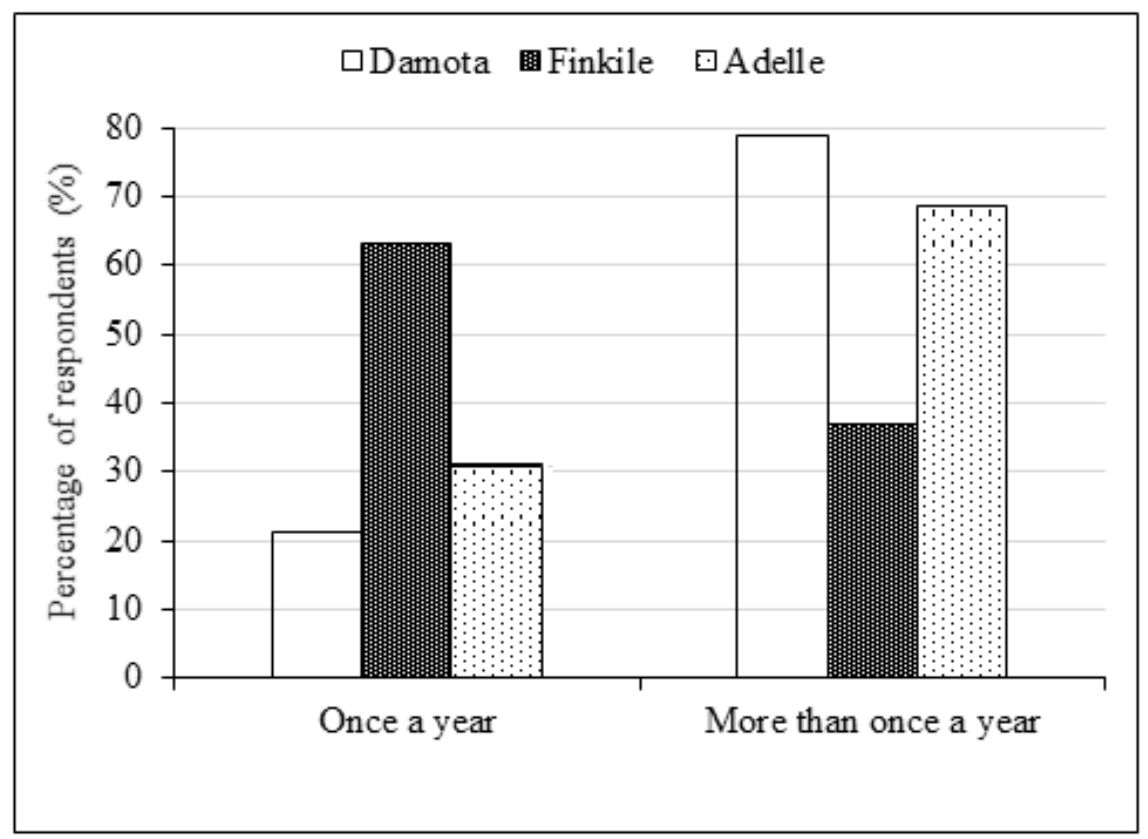

Figure 6. The frequency of crop cultivation in the three kebeles of the Haramaya District (Source: Elaborated by the Authors).

\subsection{Irrigation Practices}

Of the surface and drip irrigation methods used in the study areas, the conventional irrigation system is surface irrigation with buckets and small canals (Figure 7). The main sources of water used for their irrigation are communal shallow wells (62\%) and rain (38\%). In addition, Figure 7 shows that the household farmers rely more on groundwater for irrigating their farms than surface water. However, we noticed that some of the farmers at the Haramaya District use a combination of groundwater and rainwater harvesting to irrigate their crops.

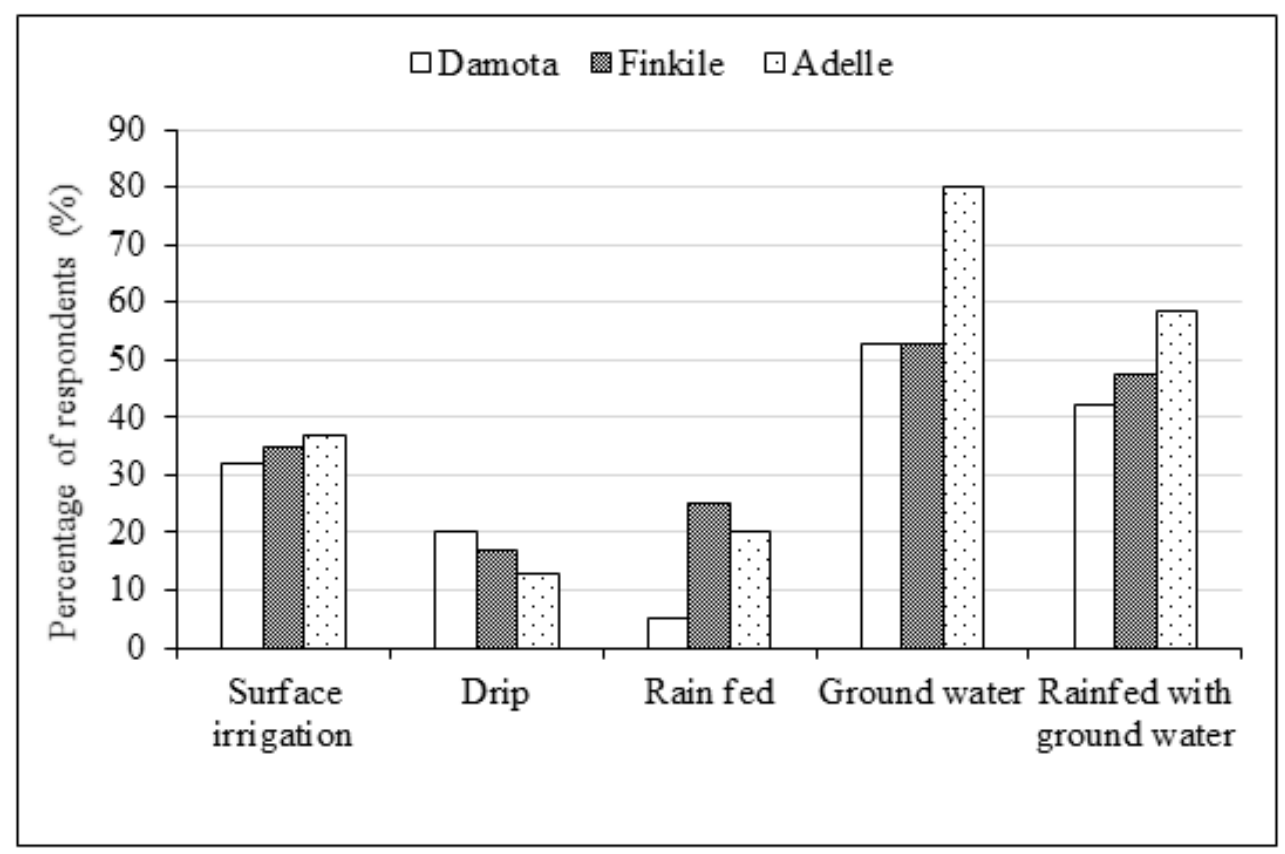

Figure 7. Types of irrigation systems practiced in the three selected kebeles of the Haramaya District (Source: Elaborated by the Authors). 
Farmers store surplus rainwater on the farm by constructing traditional small ponds locally called Ellas and use that water as a reserve in case the rain stops before crops maturity or for their homesteads irrigation. This practice also fills the gap in rainfall deficiency throughout the rainy season by conserving water on farms or close to farms. The stored water is usually used to manually irrigate crops, which include potatoes, carrots, garlic, onions, cabbage and maize. These are crops consumed at the household levels and used to generate income (if there is surplus production). Overall, the newly introduced drip irrigation with a hand-dug well water supply systems to the pilot farmers gave them assurance of a more regular water supply and enough distribution of water, which even helped them to cultivate more crops during the dry period.

\subsection{Crop Water Productivity and Crop Yield}

Figure 8 illustrates the effect of the application of a drip irrigation system on agricultural production for both intervention and non-intervention pilots of the study area. For both pilots, the crop yield and water productivity were measured for the period of once a year out of two cropping seasons. The crops were irrigated using a surface irrigation system from communal wells for the 50 non-pilots, and drip irrigation and hand-dug wells systems for the 10 pilots. While we carried out the analyses for all crops grown at the three selected kebeles, we only present and demonstrate the new irrigation intervention impacts on potato yield, which has been commonly practiced by the farmers.

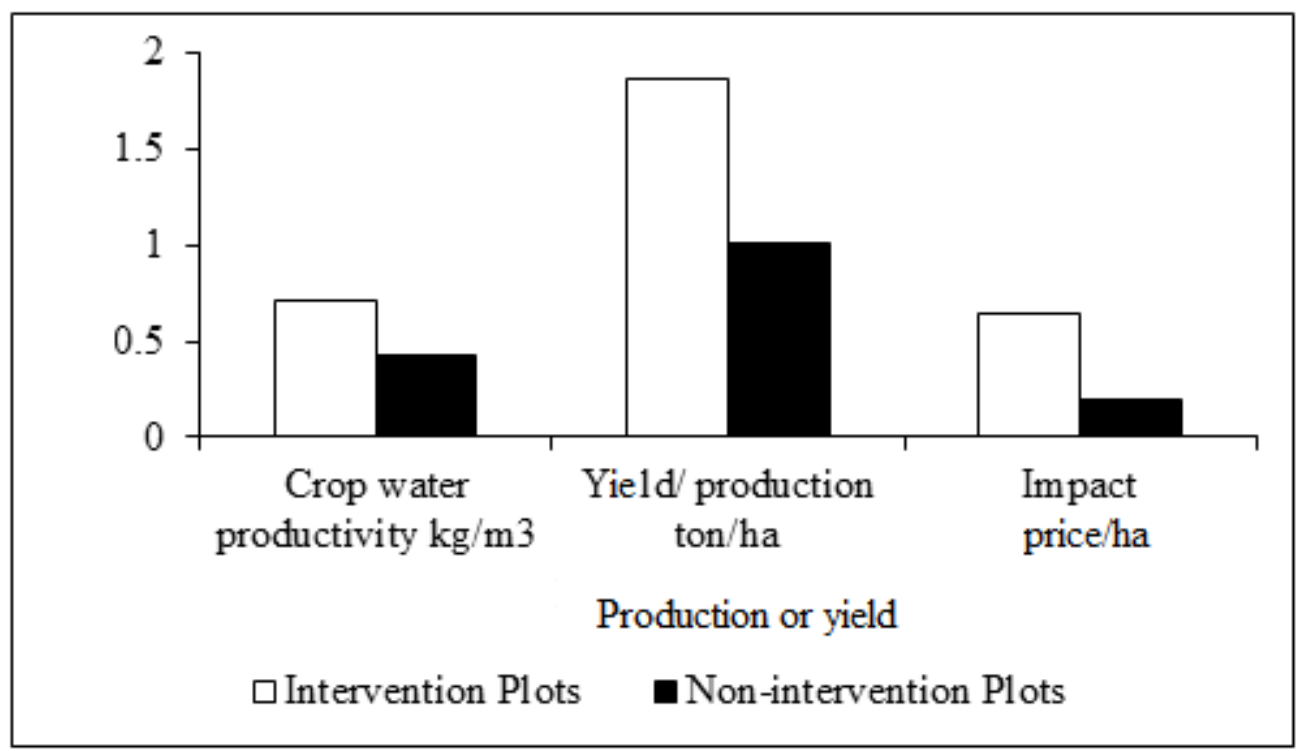

Figure 8. A comparison between intervention and no-intervention plots (Source: Elaborated by the Authors).

Compared to non-intervention farms, more water for irrigation is available in the intervention farms, which is mainly due to the use of private hand-dug wells and drip irrigation systems. Additionally, the availability of a private supplementary water source encouraged the farmers to irrigate their crops regularly and effectively with the drip irrigation system. The latter also ensured efficient irrigation water use and uniform distribution of water to all the grown crops. The introduced drip irrigation system was able to uniformly distribute the water for about $65 \%$ of the farmland. Thus, it resulted in a general increase in the quantity of crop production. Figure 9 presents the crop yields (by weight) monitored before and after the deployment of drip irrigation, whereas Figure 10 reports yield differences compared to the non-intervention farms. Figure 10 clearly indicates that the newly introduced drip irrigation system (intervention) increased yields by 56 to $120 \%$ for all crops (except maize) compared to the traditional (non-intervention) farming system. The findings generally indicate that the adoption of drip irrigation and the provision of hand-dug wells to the 
household farmers significantly improved their crop yields and potentially influenced their food self-sufficiency. This in turn can potentially help the household farmers to generate more incomes and improve their livelihoods.

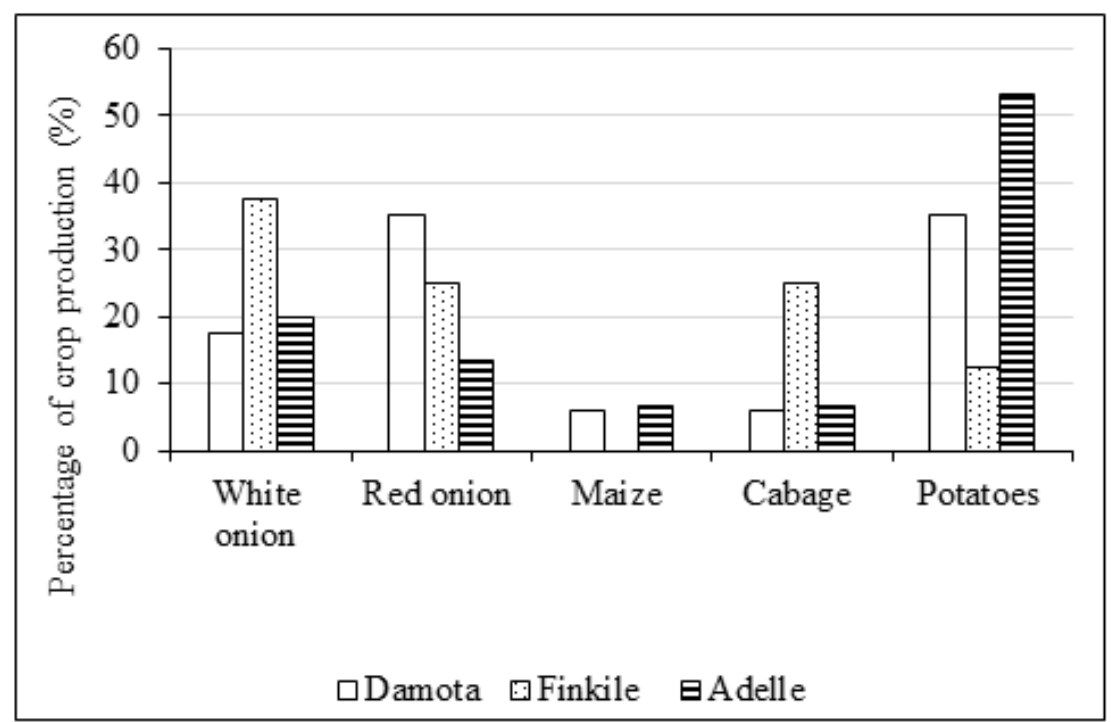

Figure 9. Types of crops grown in the three selected kebeles of the Haramaya District (Source: Elaborated by the Authors).

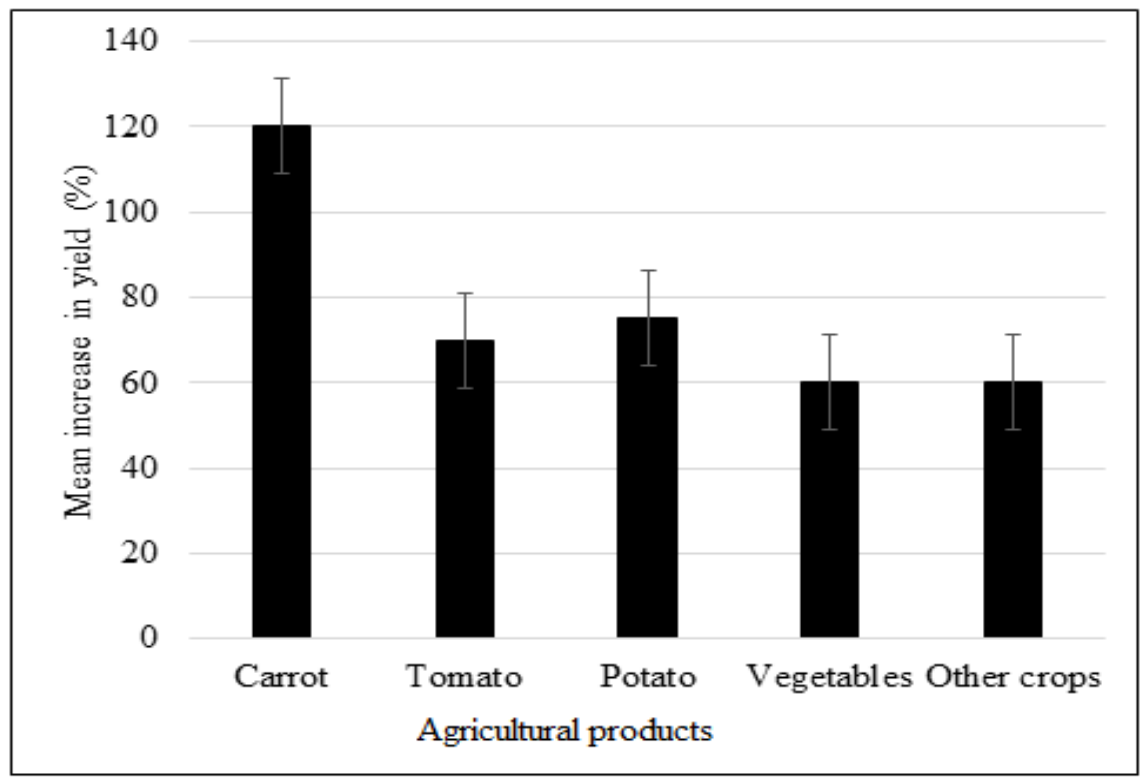

Figure 10. Mean percentage increment in crop yields of household farmers (intervention pilot) compared to non-intervention pilot (Source: Elaborated by the Authors).

\subsection{Farmers' Perception on the Drip Irrigation and Self-Provided Water Supply Schemes}

Group discussion and interviews with the household farmers identified the perception of the farmers to the newly introduced drip irrigation and hand-dug wells water supply systems. Results indicate most of the respondents $(76 \%)$ developed an awareness of the efficiency of drip irrigation system from the initial on-farm training and its benefits. This result is in line with the previous studies done in other part of Ethiopia [32,45,46]. More importantly, most of the farmers showed their interest because the new intervention helped to efficiently use irrigation water, save their working hours in the field and minimize the workload of women, which have been prone to gender-sensitive $[38,47,66]$. Farmers 
also responded regarding the easy use of the adopted irrigation system, while it provides efficient management of irrigation water use and improves their crop yields. This is consistent with previous studies on sustainable water management and an increase in crop water productivity $[48,55,67]$.

Further analysis of the affordability of the drip irrigation system indicated that the majority $(71 \%)$ of the respondents rated the drip irrigation system as affordable, and the remaining $29 \%$ considered as unaffordable without getting any subsidy. Respondents showed a preference for drip irrigation kits with barrel drums and triddle pumps than the traditional buckets and washer pumps because of their more comfortable operation and maintenance. Furthermore, most of the respondents (77\%) showed a preference for self-supply or private water sources (hand-dug wells) over public sources (communal ponds). The farmers had also expressed their interest in the use of the private water sources over the communal water supply sources as the private source provides more privacy and control with water utilization and distribution and and thus avoids water conflicts. The remaining $23 \%$ manifested their preferences for the shared water source. Overall, the majority of the farmers showed a positive perception on the introduced drip irrigation system compared to the traditional irrigation system. However, at the same time, the farmers also pointed out somechallenges related to drip irrigation systems, such as lines and hand-dug wells maintenance, lack of access to drip irrigation kits in the local markets, updates and skills related dirp irrigation system implementation, and the need for financial investments. This clearly highlights that the introduced irrigation and hand-dug water supply schemes need technical and financial supports from local to federal governments and agencies to maintain the introduced drip irrigation systems and further improve the livelihoods of the rural farmers and communities.

\section{Conclusions and Recommendations}

This study assessed the impacts of adopting drip irrigation and private hand-dug well irrigation water supply schemes on crop water productivity and yields compared to the traditional surface irrigation and communal water supply schemes. We applied this study at the household level with selected household farmers from three selected kebeles of the Haramaya District, which is located in the eastern part of Ethiopia. We found that the newly introduced drip irrigation combined with supplementary water sources from hand-dug wells significantly improved the crop water productivity and yields of all the household farmers, compared to the traditional surface irrigation and communal irrigation water supply schemes. The new method also helped to reduce over-exploitation of irrigation water use, the amount of labour and time needed to irrigate their crops, and stress and workload on women, including providing them a more flexible system to increase their farm size and grow a variety crops. Furthermore, farmers showed higher acceptance of the adopted drip irrigation system and private water sources than traditional irrigation and communal water supply systems, which is promising to upscale the new irrigation technology to the other kebeles of the Haramaya District. Overall, this study clearly showed that a newly drip irrigation system coupled with the utilization of hand-dug well water supply schem outperformed the traditionally applied irrigation system and communal water sources, to improve crop water productivity and yields at household levels. Although the majority of the selected household farmers showed a positive perception on the use of the new drip irrigation and water supply schemes, they have had concerns about their financial capabilities and skills to further invest and maintain the adopted irrigation technology. Therefore, the farmers need financial and technical skills supports, collaborations, and participations from different stakeholders and sectors such as the government, non-governmental organizations, farmers' associations and other relevant agencies. In addition, we also noticed that enhancing a capacity building and access to market places for the household farmers are clearly needed for efficient and cost-effective use of the introduced drip irrigation systems and improvement of crop water productivity and yields of the selected farmers.

In general, we concluded that the introduced drip irrigation supplemented with the hand-dug well water supply schemes were proved to have potential benefits, improve the livelihoods and motivate the acceptance by the selected household farmers and elsewhere with similar characteristics. However, 
this study has some limitations that need to be addressed in future studies. These include considering other factors such as socio-economic and biophysical characteristics (soil types and depths, nutrient availability, landscape, rainfall patterns) and other environmental factors, which are particularly expected to affect the perception of household farmers on the introduced drip irrigation system.

Author Contributions: M.D. conceptualized, designed, performed, analyzed, intepreted, dafted and edited the paper. O.T.L. and M.O.D. conceived and supervised the research, contributed ideas during analyses, reviewed and edited the paper. All authors have read and agreed to the published version of the manuscript.

Funding: This research received no external funding.

Acknowledgments: The Haramaya University, Haramaya Woreda Bureau of Irrigation and Water Resources, Haramaya Woreda Bureau of Agriculture, Participatory Integrated Development of Lake Haramaya Watershed Project Office and smallholder farmers in the three kebeles all are warmly acknowledged for their kind support for the accomplishment of the project.

Conflicts of Interest: The authors declare no conflict of interest.

\section{References}

1. Sadoff, C. Managing Water Resources to Maximize Sustainable Growth: A World Bank Water Resources Assistance Strategy for Ethiopia; World Bank Publications: Washington, DC, USA, 2019.

2. United Nations Department of Economic and Social Affairs. Population Division. World Population Prospects 2019: Highlights; United Nations Department of Economic and Social Affairs: New York, NY, USA, 2019.

3. Changnon, S.A.; Pielke, R.A., Jr.; Changnon, D.; Sylves, R.T.; Pulwarty, R. Human factors explain the increased losses from weather and climate extremes. Bull. Am. Meteorol. Soc. 2000, 81, 437-442. [CrossRef]

4. Elliott, J.; Deryng, D.; Müller, C.; Frieler, K.; Konzmann, M.; Gerten, D.; Glotter, M.; Flörke, M.; Wada, Y.; Best, N. Constraints and potentials of future irrigation water availability on agricultural production under climate change. Proc. Natl. Acad. Sci. USA 2014, 111, 3239-3244. [CrossRef]

5. Easterling, D.R.; Meehl, G.A.; Parmesan, C.; Changnon, S.A.; Karl, T.R.; Mearns, L.O. Climate extremes: Observations, modeling, and impacts. Science 2000, 289, 2068-2074. [CrossRef] [PubMed]

6. Burnham, M.; Ma, Z. Linking smallholder farmer climate change adaptation decisions to development. Clim. Dev. 2016, 8, 289-311. [CrossRef]

7. Haddeland, I.; Heinke, J.; Biemans, H.; Eisner, S.; Flörke, M.; Hanasaki, N.; Konzmann, M.; Ludwig, F.; Masaki, Y.; Schewe, J. Global water resources affected by human interventions and climate change. Proc. Natl. Acad. Sci. USA 2014, 111, 3251-3256. [CrossRef]

8. Morea, D.; Balzarini, M. Financial sustainability of a public-private partnership for an agricultural development project in Sub-Saharan Africa. Agric. Econ. 2018, 64, 389-398.

9. Nelson, G.C.; Rosegrant, M.W.; Koo, J.; Robertson, R.; Sulser, T.; Zhu, T.; Ringler, C.; Msangi, S.; Palazzo, A.; Batka, M. Climate Change: Impact on Agriculture and Costs of Adaptation; International Food Policy Research Institute: Washington, DC, USA, 2009; Volume 21.

10. Teklewold, H.; Mekonnen, A.; Kohlin, G.; Di Falco, S. Does adoption of multiple climate-smart practices improve farmers'climate resilience? Empirical evidence from the nile basin of ethiopia. Clim. Chang. Econ. 2017, 8, 1750001. [CrossRef]

11. Food and Agriculture Organization of the United Nations. Country Gender Assessment: Ethiopia; Food and Agriculture Organization of the United Nations: Rome, Italy, 2019.

12. Meze-Hausken, E. Contrasting climate variability and meteorological drought with perceived drought and climate change in northern Ethiopia. Clim. Res. 2004, 27, 19-31. [CrossRef]

13. Mishra, A.K.; Singh, V.P. A review of drought concepts. J. Hydrol. 2010, 391, 202-216. [CrossRef]

14. Machado Mendes, D.; Paglietti, L. Ethiopia: Irrigation Market Brief; Food and Agriculture Organization of the United Nations: Rome, Italy, 2015.

15. Awulachew, S.B.; Merrey, D.; Kamara, A.; Van Koppen, B.; de Vries, F.P.; Boelee, E. Experiences and Opportunities for Promoting Small-Scale/Micro Irrigation and Rainwater Harvesting for Food Security in Ethiopia; International Water Management Institute: Colombo, Sri Lanka, 2005; Volume 98.

16. Riar, A.; Mandloi, L.S.; Poswal, R.S.; Messmer, M.M.; Bhullar, G.S. A diagnosis of biophysical and socio-economic factors influencing farmers' choice to adopt organic or conventional farming systems for cotton production. Front. Plant Sci. 2017, 8, 1289. [CrossRef] 
17. Steuer, R.E.; Na, P. Multiple criteria decision making combined with finance: A categorized bibliographic study. Eur. J. Oper. Res. 2003, 150, 496-515. [CrossRef]

18. Morea, D.; Balzarini, M. Bankability of a public private partnership in agricultural sector: A project in Sub Saharan Africa. Agric. Econ. 2019, 65, 212-222. [CrossRef]

19. Kløve, B.; Ala-Aho, P.; Bertrand, G.; Gurdak, J.J.; Kupfersberger, H.; Kværner, J.; Muotka, T.; Mykrä, H.; Preda, E.; Rossi, P.M. Climate change impacts on groundwater and dependent ecosystems. J. Hydrol. 2014, 518, 250-266. [CrossRef]

20. Andersson, L.; Samuelsson, P.; Kjellström, E. Assessment of climate change impact on water resources in the Pungwe river basin. Tellus A 2011,63, 138-157. [CrossRef]

21. Bailey, R.T.; Wible, T.C.; Arabi, M.; Records, R.M.; Ditty, J. Assessing Regional-Scale Spatio-Temporal Patterns of Groundwater-Surface Water Interactions using a Coupled SWAT-MODFLOW model. Hydrol. Process. 2016, 30, 4420-4433. [CrossRef]

22. Treidel, H.; Martin-Bordes, J.L.; Gurdak, J.J. Climate Change Effects on Groundwater Resources: A Global Synthesis of Findings and Recommendations; CRC Press: Boca Raton, FL, USA, 2011.

23. Keane, J.; Page, S.; Kennan, J. Climate Change and Developing Country Agriculture; International Centre for Trade and Sustainable Development: Geneva, Switzerland, 2009.

24. Green, T.R.; Taniguchi, M.; Kooi, H.; Gurdak, J.J.; Allen, D.M.; Hiscock, K.M.; Treidel, H.; Aureli, A. Beneath the surface of global change: Impacts of climate change on groundwater. J. Hydrol. 2011, 405, 532-560. [CrossRef]

25. Strzepek, K.M.; McCluskey, A. The Impacts of Climate Change on Regional Water Resources and Agriculture in Africa; World Bank Publications: Washington, DC, USA, 2007; Volume 4290.

26. Deressa, T.; Hassan, R.M.; Ringler, C. Measuring Ethiopian Farmers' Vulnerability to Climate Change across Regional States; International Food Policy Research Institute: Washington, DC, USA, 2008.

27. Brauman, K.A.; Siebert, S.; Foley, J.A. Improvements in crop water productivity increase water sustainability and food security-A global analysis. Environ. Res. Lett. 2013, 8, 024030. [CrossRef]

28. Knox, J.; Kay, M.; Weatherhead, E. Water regulation, crop production, and agricultural water management-Understanding farmer perspectives on irrigation efficiency. Agric. Water Manag. 2012, 108, 3-8. [CrossRef]

29. Ogato, G.S.; Boon, E.K.; Subramani, J. Improving access to productive resources and agricultural services through gender empowerment: A case study of three rural communities in Ambo District, Ethiopia. J. Human Ecol. 2009, 27, 85-100. [CrossRef]

30. Ambaw, G.; Tadesse, M.; Mungai, C.; Kuma, S.; Radeny, M.; Tamene, L.; Solomon, D. Gender Assessment for Women's Economic Empowerment in Doyogena Climate-Smart Landscape in Southern Ethiopia; CGIAR Research Program on Climate Change, Agriculture and Food Security: Wageningen, The Netherlands, 2019.

31. Debela, N.; Mohammed, C.; Bridle, K.; Corkrey, R.; McNeil, D. Perception of climate change and its impact by smallholders in pastoral/agropastoral systems of Borana, South Ethiopia. SpringerPlus 2015, 4, 236. [CrossRef]

32. Villani, L.; Castelli, G.; Hagos, E.Y.; Bresci, E. Water productivity analysis of sand dams irrigation farming in northern Ethiopia. J. Agric. Environ. Int. Dev. 2018, 112, 139-160.

33. Castelli, G.; Bresci, E.; Castelli, F.; Hagos, E.Y.; Mehari, A. A participatory design approach for modernization of spate irrigation systems. Agric. Water Manag. 2018, 210, 286-295. [CrossRef]

34. Awulachew, S.B.; Ahmed, A.; Haileselassie, A.; Yilma, A.D.; Bashar, K.; McCartney, M.P.; Steenhuis, T. Improved Water and Land Management in the Ethiopian Highlands and Its Impact on Downstream Stakeholders Dependent on the Blue Nile; International Livestock Research Institute: Nairobi, Kenya, 2010.

35. Azadi, H.; De Rudder, F.; Vlassenroot, K.; Nega, F.; Nyssen, J. Targeting international food aid programmes: The case of productive safety net programme in Tigray, Ethiopia. Sustainability 2017, 9, 1716. [CrossRef]

36. Aldababseh, A.; Temimi, M.; Maghelal, P.; Branch, O.; Wulfmeyer, V. Multi-criteria evaluation of irrigated agriculture suitability to achieve food security in an arid environment. Sustainability 2018, 10, 803. [CrossRef]

37. Dile, Y.T.; Rockström, J.; Karlberg, L. Suitability of water harvesting in the Upper Blue Nile Basin, Ethiopia: A first step towards a mesoscale hydrological modeling framework. Adv. Meteorol. 2016, 2016, 5935430. [CrossRef]

38. Imburgia, L. Irrigation and equality: An integrative gender-analytical approach to water governance with examples from Ethiopia and Argentina. Water Altern. 2019, 12, 571-587. 
39. Tsige, M. Who Benefits from Production Outcomes? Gendered Production Relations among Climate-Smart Agriculture Technology Users in Rural Ethiopia. Rural Sociol. 2019, 84, 799-825. [CrossRef]

40. Arora, D.; Rada, C. Gender differences in time and resource allocation in rural households in Ethiopia. In Proceedings of the Annual Conference of the American Economic Association, San Diego, CA, USA, 4-6 January 2013.

41. Austin, A.T.; Vitousek, P. Nutrient dynamics on a precipitation gradient in Hawaii. Oecologia 1998, 113, 519-529. [CrossRef]

42. Chamberlin, J.; Schmidt, E. Ethiopian agriculture: A dynamic geographic perspective. Food Agric. Ethiop. 2012, 17, 21-52.

43. Awulachew, S.B. Modelling natural conditions and impacts of consumptive water use and sedimentation of Lake Abaya and Lake Chamo, Ethiopia. Lakes Reserv. 2006, 11, 73-82. [CrossRef]

44. Ministry of Finance and Economic Development. Building on Progress A Plan for Accelerated and Sustained Development to End Poverty (PASDEP); Ministry of Finance and Economic Development: Addis Ababa, Ethiopia, 2006; Volume 1.

45. Khairo, S.; Battese, G.E.; Mullen, J. Agriculture, food insecurity and agricultural policy in Ethiopia. Outlook Agric. 2005, 34, 77-82. [CrossRef]

46. Zewdie, M.C.; Van Passel, S.; Moretti, M.; Annys, S.; Tenessa, D.B.; Ayele, Z.A.; Tsegaye, E.A.; Cools, J.; Minale, A.S.; Nyssen, J. Pathways how irrigation water affects crop revenue of smallholder farmers in northwest Ethiopia: A mixed approach. Agric. Water Manag. 2020, 233, 106101. [CrossRef]

47. Johnson, N.L.; Kovarik, C.; Meinzen-Dick, R.; Njuki, J.; Quisumbing, A. Gender, assets, and agricultural development: Lessons from eight projects. World Dev. 2016, 83, 295-311. [CrossRef]

48. Jovanovic, N.; Musvoto, C.; De Clercq, W.; Pienaar, C.; Petja, B.; Zairi, A.; Hanafi, S.; Ajmi, T.; Mailhol, J.C.; Cheviron, B. A comparative analysis of yield gaps and water productivity on smallholder farms in Ethiopia, South Africa and Tunisia. Irrig. Drain. 2020, 69, 70-87. [CrossRef]

49. Araya, T.; Nyssen, J.; Govaerts, B.; Deckers, J.; Cornelis, W.M. Impacts of conservation agriculture-based farming systems on optimizing seasonal rainfall partitioning and productivity on vertisols in the Ethiopian drylands. Soil Tillage Res. 2015, 148, 1-13. [CrossRef]

50. Nakawuka, P.; Langan, S.; Schmitter, P.; Barron, J. A review of trends, constraints and opportunities of smallholder irrigation in East Africa. Glob. Food Secur. 2018, 17, 196-212. [CrossRef]

51. Awulachew, S.B.; Yilma, A.D.; Loulseged, M.; Loiskandl, W.; Ayana, M.; Alamirew, T. Water Resources and Irrigation Development in Ethiopia; International Water Management Institute: Colombo, Sri Lanka, 2007; Volume 123.

52. Grum, B.; Assefa, D.; Hessel, R.; Woldearegay, K.; Ritsema, C.J.; Aregawi, B.; Geissen, V. Improving on-site water availability by combining in-situ water harvesting techniques in semi-arid Northern Ethiopia. Agric. Water Manag. 2017, 193, 153-162. [CrossRef]

53. Farjad, B.; Pooyandeh, M.; Gupta, A.; Motamedi, M.; Marceau, D. Modelling Interactions between Land Use, Climate, and Hydrology along with Stakeholders' Negotiation for Water Resources Management. Sustainability 2017, 9, 2022. [CrossRef]

54. Hagos, F.; Makombe, G.; Namara, R.E.; Awulachew, S.B. Importance of Irrigated Agriculture to the Ethiopian Economy: Capturing the Direct Net Benefits of Irrigation; International Water Management Institute: Colombo, Sri Lanka, 2009; Volume 128.

55. Makombe, G.; Namara, R.E.; Awulachew, S.B.; Hagos, F.; Ayana, M.; Kanjere, M. An analysis of the productivity and technical efficiency of smallholder irrigation in Ethiopia. Water SA 2017, 43, 48-57. [CrossRef]

56. Tadesse, N.; Bheemalingeswara, K.; Abdulaziz, M. Hydrogeological investigation and groundwater potential assessment in Haromaya watershed, Eastern Ethiopia. Momona Ethiop. J. Sci. 2010, 2. [CrossRef]

57. Tian, Y.; Zheng, Y.; Wu, B.; Wu, X.; Liu, J.; Zheng, C. Modeling surface water-groundwater interaction in arid and semi-arid regions with intensive agriculture. Environ. Model. Softw. 2015, 63, 170-184. [CrossRef]

58. Alwan, I.A.; Karim, H.H.; Aziz, N.A. Groundwater aquifer suitability for irrigation purposes using multi-Criteria decision approach in Salah Al-Din Governorate/Iraq. AgriEngineering 2019, 1, 303-323. [CrossRef]

59. Brouwer, C.; Prins, K.; Heibloem, M. Irrigation Water Management: Irrigation Scheduling; Food and Agriculture Organization of the United Nations: Rome, Italy, 1989. 
60. Pereira, L.S.; Oweis, T.; Zairi, A. Irrigation management under water scarcity. Agric. Water Manag. 2002, 57, 175-206. [CrossRef]

61. Perry, C. Improving Irrigation Management in Conditions of Scarcity: Myth vs Truth; Global Water Forum: Brasilia, Brazil, 2018.

62. Setegn, S.G.; Chowdary, V.; Mal, B.; Yohannes, F.; Kono, Y. Water balance study and irrigation strategies for sustainable management of a tropical Ethiopian lake: A case study of Lake Alemaya. Water Resour. Manag. 2011, 25, 2081-2107. [CrossRef]

63. Muleta, S.; Yohannes, F.; Rashid, S. Soil erosion assessment of Lake Alemaya catchment, Ethiopia. Land Degrad. Dev. 2006, 17, 333-341. [CrossRef]

64. Meshesha, D.T.; Tsunekawa, A.; Tsubo, M.; Ali, S.A.; Haregeweyn, N. Land-use change and its socio-environmental impact in Eastern Ethiopia's highland. Reg. Environ. Chang. 2014, 14, 757-768. [CrossRef]

65. Stillhardt, B.; Ghebru, B.; Mehari, A. Small-Scale Micro Irrigation in Eritrea: A Feasibility Study on the Introduction of Affordable Micro Irrigtion Technology in Eritrea, Environmend (CDE); University of Bern: Bern, Switzerland, 2003.

66. Wakeyo, M.B.; Gardebroek, C. Share of irrigated land and farm size in rainwater harvesting irrigation in Ethiopia. J. Arid Environ. 2017, 139, 85-94. [CrossRef]

67. Rockström, J.; Falkenmark, M. Agriculture: Increase water harvesting in Africa. Nature 2015, 519, $283-285$. [CrossRef]

(C) 2020 by the authors. Licensee MDPI, Basel, Switzerland. This article is an open access article distributed under the terms and conditions of the Creative Commons Attribution (CC BY) license (http://creativecommons.org/licenses/by/4.0/). 